\title{
Vice-Chancellors on the Move
}

THE Committee of Vice-Chancellors and Principals, hitherto a somewhat trappist organization, has now published the first report in its history. The committee says that it has been led to do this chiefly because of the way in which, in the past two years, it has become "a focus of university opinion and an instrument of university cooperation". The committee also promises that from now on it will report once a year. If future documents in the series are as trenchant as that which has now appeared, nobody will be disappointed.

The report reviews much of what has happened in the university quinquennium now past (1962-67) and says it was from the beginning obvious that this quinquennium would present exceptional problems. First, the number of qualified sixth formers and the desire for higher education were increasing more rapidly than official plans allowed. Second, the expansion in higher education meant the establishment of new universities. Third, in 1960 the British Government accepted the recommendations of the Anderson report by encouraging everyone with two passes in the A-level examination to seek higher education. Finally, the Robbins Commission began its work, and its report in 1963 presented the universities with constitutional, academic, administrative and financial problems.

The vice-chancellors do not hide their dismay at the way the relationship between the Government and the universities has developed. The Vice-Chancellors' Committee in its evidence to the Robbins Commission "opposed the suggestion that the Ministry of Education should have responsibility for providing all funds for education including the universities. We still thought the solution lay in strengthening the prestige and authority of the University Grants Committee in its relations with the Treasury". The Robbins report recommended a single minister for arts and science separate from the Ministry of Education and responsible for the autonomous institutions, which would be controlled on the grants committee principle.

In spite of this recommendation and the opinions of the vice-chancellors, however, on April 1, 1964, a Secretary of State for Education and Science was made responsible for the whole field of education. Further, the Joint Permanent Under-Secretary responsible for universities was within a few months quietly jettisoned, just as the Vice-Chancellors' Committee had feared. The universities' anxieties about their autonomy were well founded. The vice-chancellors see only ono advantage in the new arrangements-that university affairs can be more regularly brought before Parliament -but they lament the lack of any regular and accepted pattern of consultation. They were not, for example, consulted before the Government promulgated its theory of a binary education system in 1966 or even when the Government decided to raise fees for foreign students. The report says that "relations between the universities and the State are delicate, and the position of the UGC is at all times fundamental; the right balance has yet to be struck". The way in which the Government gave the Comptroller and Auditor General access to the books of the universities still rankles.

The establishment of the Department of Education and Science meant new relations between the UGC- "a committee independent of politics and not subject to ministerial direction"- and the administration on one hand and the vice-chancellors on the other. The report says that although Sir John Wolfenden and Dr D. G. Christopherson, the respective chairmen of the two committees, have maintained close and regular contact, it has proved less easy to devise a system whereby their respective committees can consult "partly owing to the special position of the UGC in its capacity of confidential adviser to the Government". Despite continued protestations of the independence of the UGC, the Committee of Vice-Chancellors clearly has misgivings.

In the report now published, the vice-chancellors complain that the British Government delayed for more than a year before arknowledging in public that estimates of the demand for university places between 1963 and 1973 could be more than adequately met by the existing universities, the new universities and the technical colleges. The vice-chancellors also put on record their discontent with the Government's handling of the upgrading of teacher training colleges into schools of education affiliated with the universities. More ominously for the Government, the vice-chancellors also raise some aw kward questions about the relationship between the universities and the polytechnics and, in particular, suggest that these may turn out to be competitors, not complementary institutions.

The report has some important things to say about the sources of university finance. Over the years, the report argues, the proportion of university funds provided directly by the central government has increased steadily until it exceeded 74 per cent in 1965-66. The vice-chancellors record with evident nostalgia the evidence by the Treasury to the Robbins Commission on the need to increase tuition fees, at present an average of about $£ 80$ for students from the United Kingdom. The vice-chancellors give it as their opinion that it would at this stage bo hard to go for the Robbins target in which tuition fees would account for rovghly 20 per cent of the income of British universities, and the fact that the committee's report says that big issues like these must wait on Government decision shows that the vice-chancellors have not yet thrown off the yoke of dependence.

On the positive side, the Universities Central Council for Admissions has been established and a joint standing committee with representatives of the vice-chancellors and the local authorities under the chairmanship of the DES was also set up to standardize administration of student grants. And, at the end of the quinquennium, arrangements were made for consultations between the vice-chancellors and the National Union of Students on student participation in running the universities. The vice-chancellors welcome the establishment of the Council for Science. Policy and the three new research councils. The report says: "The continuance of the dual system of support of research in the universities by the UGC on the one hand and the research councils on the other was strongly supported. UGC participation was held by our committee to be essential to maintain the interdependence of university teaching and research." 